\title{
THE END OF BYZANTIUM
}





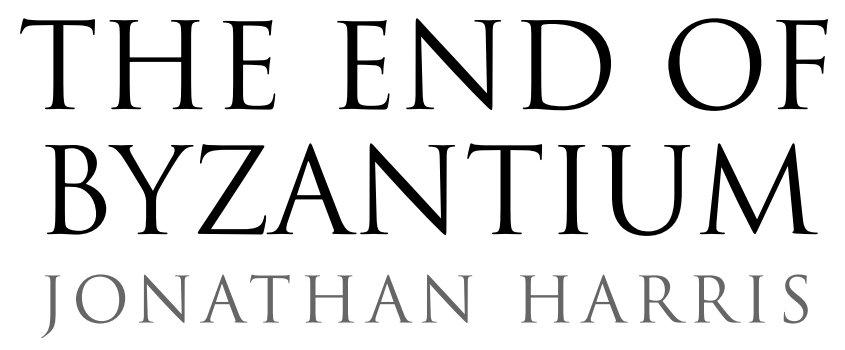

YALE UNIVERSITY PRESS NEW HAVEN AND LONDON 


\section{In Memory of Konstantinos Ikonomopoulos \\ (1980-2009)}

Copyright ( 2010 Jonathan Harris

All rights reserved. This book may not be reproduced in whole or in part, in any form (beyond that copying permitted by Sections 107 and 108 of the U.S. Copyright Law and except by reviewers for the public press) without written permission from the publishers.

For information about this and other Yale University Press publications, please contact: U.S. Office: sales.press@yale.edu www.yalebooks.com

Europe Office: sales @yaleup.co.uk www.yalebooks.co.uk

Set in Garamond Pro by IDSUK (DataConnection) Ltd

Printed in Great Britain by TJ International Ltd, Padstow, Cornwall

Library of Congress Cataloging-in-Publication Data

Harris, Jonathan.

The end of Byzantium / Jonathan Harris.

p. $\mathrm{cm}$.

ISBN 978-0-300-11786-8 (cl:alk. paper)

1. Byzantine Empire-History-Manuel II Palaeologus, 1391-1425.

2. Byzantine Empire-History-John VIII Palaeologus, 1425-1448. 3. Byzantine

Empire-History-Constantine XI Dragases, 1448-1453. I. Title.

DF639.H37 2011

$949.5^{\prime} 03-\mathrm{dc} 22$

A catalogue record for this book is available from the British Library.

1098766543221 